\title{
Muntingia calabura L Leaves Extract Inhibits Glucosyltransferase Activity of Streptococcus mutans
}

\author{
Rina Isnarianti ${ }^{1}$, Ivan A. Wahyudi², Rini M. Puspita ${ }^{2}$ \\ ${ }^{1}$ Undergraduate Program, Faculty of Dentistry, Universitas Gadjah Mada, Yogyakarta 55281, Indonesia \\ ${ }^{2}$ Departement of Biomedical Science, Faculty of Dentistry, Universitas Gadjah Mada, Yogyakarta 55281, \\ Indonesia \\ Correspondencee-mail: ivanocovic@yahoo.com
}

\begin{abstract}
Jamaican cherry (Muntingia calabura L.) is one type of plants that used by Indonesians as traditional medicine. Muntingia calabura L. leaves contain tannins, flavonoids, and polyphenolics that are believed to have capability as antibacterial agent. One of bacteria that can cause dental caries is Steptococcus mutans that has glucosyltransferase (GTF) which is capable to catalyze glucan synthesis in the progression of dental caries. Objective: To study the effect of 10\% Muntingia calabura L. leaves extract toward S. mutans GTF activity. Methods: This research used $10 \%$ concentration of Muntingia calabura L. leaves, chlorhexidine gluconate $0.12 \%$, and sterile distilled water, as the treatment, positive control and negative control group, respectively. GTF activity assays through fructose extensive area analysis by using High Performance Liquid Chromatography (HPLC). Fructose extensive area determined based on time retention from each groups. Fructose concentrations were expressed in percent $(\%)$ then converted into $\mu \mathrm{mol} / \mathrm{ml}$ fructose that defined as a unit of GTF activity. The data was analyzed by one-way ANOVA. Results: One-way ANOVA analysis showed a significantly lower GTF activity in the treatment group compared to the negative control $(p<0.05)$. Conclusion: $10 \%$ Muntingia calabura L. leaves extract capable to inhibit $S$. mutans GTF activity.
\end{abstract}

\begin{abstract}
ABSTRAK
Ekstrak daun kersen menghambat aktivitas glukosiltransferase pada Streptococcus mutans. Kersen (Muntingia calabura L.) merupakan salah satu jenis tanaman yang digunakan masyarakat Indonesia sebagai obat tradisional. Daun kersen memiliki kandungan tanin, flavonoid, serta senyawa polifenol yang dipercaya memiliki kemampuan sebagai antibakteri. Salah satu bakteri utama penyebab karies gigi adalah Streptococcus mutans yang memiliki enzim glukosiltransferase (GTF) yang mampu mengatalisis sintesis glukan dalam proses terjadinya karies gigi. Tujuan: Mengetahui pengaruh pemberian ekstrak daun kersen konsentrasi 10\% terhadap aktivitas GTF S. mutans. Metode: Penelitian ini menggunakan ekstrak daun kersen konsentrasi 10\% sebagai perlakuan, klorheksidin glukonat 0,12\% sebagai kontrol positif, dan akuades sebagai kontrol negatif. Pengujian aktivitas GTF dilakukan dengan menghitung luas area fruktosa menggunakan High Performance Liquid Chromatography (HPLC). Pembacaan luas area fruktosa dilakukan berdasarkan waktu retensi dari masing-masing kelompok perlakuan. Konsentrasi fruktosa dinyatakan dalam persen (\%), selanjutnya dikonversikan ke dalam satuan $\mu \mathrm{mol} / \mathrm{mL}$ fruktosa yang didefinisikan sebagai satu unit aktivitas enzim GTF. Hasil: Analisis data hasil penelitian dengan one-way ANOVA menunjukkan terdapat penurunan aktivitas enzim GTF yang bermakna antarkelompok perlakuan $(p<0.05)$. Simpulan: Ekstrak daun kersen konsentrasi 10\% dapat menghambat aktivitas GTF S. mutans.
\end{abstract}

Key words: glucosyltransferase, Muntingia calabura L., Streptococcus mutans 


\section{PENDAHULUAN}

Karies gigi merupakan penyakit multifaktorial yang terjadi karena adanya interaksi dari beberapa faktor yaitu faktor penjamu, bakteri, substrat, dan waktu. ${ }^{1}$ Prevalensi karies gigi di Indonesia masih cukup tinggi, Survei Kesehatan Nasional 2002 menunjukkan prevalensi karies gigi di Indonesia berkisar $60 \% .^{2}$ Riset Kesehatan Dasar (RISKESDAS) tahun 2007 menunjukkan indeks DMF-T masih cukup tinggi yaitu 4,85 yang berarti ratarata kerusakan gigi pada penduduk Indonesia 5 buah gigi per orang. ${ }^{3}$ Karies gigi terjadi secara multifaktorial dengan melibatkan beberapa faktor, yaitu faktor penjamu, substrat, agen, dan waktu. Gigi dan saliva berperan sebagai faktor penjamu (host), karbohidrat sebagai substrat (makanan), dan agen mikroorganisme (bakteri) dari plak. Interaksi dari faktor-faktor tersebut secara bersamaan menyebabkan terjadinya karies gigi. ${ }^{4}$

Bakteri memiliki peranan penting dalam terjadinya karies gigi, salah satu bakteri yang dominan dalam rongga mulut dan merupakan bakteri utama penyebab timbulnya karies gigi adalah Streptococcus mutans. ${ }^{5}$ Karakteristik dari bakteri $S$. mutans antara lain: mampu menyintesis polisakarida ekstraseluler glukan ikatan $\alpha$ (1-3) yang tidak larut dalam air, dapat memproduksi asam laktat melalui proses homofermentasi, membentuk koloni yang melekat dengan erat pada permukaan gigi, dan lebih bersifat asidogenik dibanding spesies Streptococcus oral lainnya. ${ }^{6}$ S. mutans mampu menyintesis polisakarida ekstraseluler karena bakteri ini mempunyai enzim glukosiltransferase (GTF) yang terdapat pada dinding sel bakteri $S$. mutans yang dapat mengatalisis sintesis glukan dari sukrosa. ${ }^{7}$

Pencegahan karies gigi dengan penggunaan agen antibakteri masih menjadi pilihan utama karena terjadinya karies gigi sangat berkaitan dengan adanya bakteri. Agen antibakteri yang kurang efektif, adanya kekebalan terhadap agen antibakteri, munculnya berbagai efek samping yang tidak diinginkan seperti rekasi hipersensitif, ataupun pewarnaan pada gigi membuat peneliti terus melakukan penelitian untuk pemanfaatan bahan alami. Pengembangan bahan alami diharapkan memiliki kemampuan yang lebih efektif sebagai agen antibakteri serta dalam berbagai pengobatan penyakit lainnya. ${ }^{8}$ Pemanfaatan bahan alam oleh masyarakat dipercaya karena bahan alam diyakini jarang menimbulkan efek samping yang merugikan dibandingkan obat atau bahan sintetis lainnya. ${ }^{9}$

Muntingia calabura L. (kersen) merupakan tanaman yang telah lama digunakan masyarakat untuk berbagai tujuan pengobatan antara lain sebagai obat batuk, sakit kuning dan asam urat. Daun dan kulit batang kersen mengandung berbagai zat kimia antara lain: polifenol, flavonoid, dan saponin..$^{10}$ Tanin merupakan senyawa turunan polifenol yang dapat merusak komponen protein dari bakteri. ${ }^{11}$ Konsentrasi ekstrak daun kersen
10\% (100.000 ppm) merupakan konsentrasi yang paling signifikan sebagai antibakteri,oleh karena itu, ekstrak daun kersen konsentrasi 10\% memiliki potensi untuk dikembangkan sebagai antikariogenik. ${ }^{12}$ Tujuan penelitian ini adalah untuk mengetahui pengaruh pemberian ekstrak daun kersen konsentrasi $10 \%$ terhadap aktivitas enzim GTF S. mutans.

\section{METODE}

Sampel dalam penelitian ini adalah enzim GTF dari supernatan bakteri $S$. mutans yang dibagi ke dalam tiga tabung berbeda untuk diamati aktivitasnya pada ekstrak daun kersen konsentrasi 10\%. Penelitian ini dibagi menjadi 3 tahap, yaitu: penyiapan ekstrak daun kersen, penyiapan enzim GTF, dan pengujian aktifitas enzim GTF.

Daun kersen yang digunakan berasal dari Sleman, Yogyakarta. Teknik ekstraksi yang dilakukan adalah teknik ekstraksi maserasi. Daun kersen dicuci bersih dan dikeringkan, kemudian disimpan di lemari pengering pada suhu $50^{\circ} \mathrm{C}$ selama $48 \mathrm{jam}$. Sampel daun kersen yang telah kering ini lalu dimasukkan kedalam mesin penyerbuk dan kemudian ditambahkan etanol $70 \%$, dicampur dengan menggunakan homogenizer dan didiamkan selama 24 jam. Campuran sampel daun kersen dan etanol $70 \%$ tersebut kemudian disaring dengan corong buchner. Ampas dibuang dan filtrat yang didapatkan diuapkan dengan vacuum rotary evaporator pemanas water bath suhu $60^{\circ} \mathrm{C}$ selama 1 jam, kemudian suhu pemanas water bath ini ditingkatkan menjadi $70^{\circ} \mathrm{C}$ sehingga diperoleh ekstrak kental daun kersen. Ekstrak kental ini dituang ke dalam cawan porselin, dipanaskan dengan water bath sambil terus diaduk.

Ektrak daun kersen (EDK) kemudian diencerkan dengan akuades steril untuk mendapatkan konsentrasi sebesar 10\%. Larutan ekstrak daun kersen konsentrasi $10 \%$ diperoleh dari pengambilan ekstrak daun kersen konsentrasi $100 \%$ dari larutan induk sebanyak $1 \mathrm{~mL}$ diencerkan dengan akuades steril sebanyak $9 \mathrm{~mL}$ sehingga didapatkan larutan sebanyak $10 \mathrm{~mL}$.

Bakteri S. mutans diinokulasikan ke dalam tabung media pembiakan yang berisi $10 \mathrm{~mL}$ BHI cair kemudian dilakukan inkubasi pada suhu $37^{\circ} \mathrm{C}$ selama 24 jam dan digetarkan dengan shaker pada $150 \mathrm{rpm} . .^{13}$ Media kultur kemudian disentrifugasi pada $1500 \mathrm{rpm}$ selama 10 menit dan diperoleh supernatan yang mengandung enzim GTF.

Sembilan tabung reaksi disediakan pada penelitian ini, tabung 1, 2, dan 3 adalah tabung perlakuan, tabung 4, 5, dan 6 adalah tabung kontrol positif, sedangkan tabung 7, 8, dan 9 adalah tabung kontrol negatif. Tabung 1, 2, dan 3 merupakan tabung perlakuan 
yang masing-masing tabung diisi dengan EDK konsentrasi 10\% sebanyak 0,025ml EDK. Ditambahkan $0,9 \mathrm{~mL}$ sukrosa $0,25 \mathrm{M}$ dalam bufer fosfat $0,2 \mathrm{M} \mathrm{pH} 7$, kemudian ditambahkan $0,1 \mathrm{~mL}$ enzim GTF, dan terakhir ditambahkan bufer fosfat $0,2 \mathrm{M} \mathrm{pH} 7$ sampai volume total $2 \mathrm{~mL}$. Tabung tabung 4, 5, dan 6 adalah tabung untuk kontrol positif, masing-masing tabung diisi dengan $0,9 \mathrm{~mL}$ sukrosa $0,25 \mathrm{M}$ dalam bufer fosfat 0,2 $\mathrm{M} \mathrm{pH} \mathrm{7,} \mathrm{kemudian} \mathrm{ditambahkan} 0,1 \mathrm{~mL}$ enzim GTF, lalu ditambahkan $0,025 \mathrm{~mL}$ klorheksidin glukonat $0,12 \%$, dan terakhir ditambahkan bufer fosfat $0,2 \mathrm{M} \mathrm{pH}$ 7 sampai volume total $2 \mathrm{~mL}$.

Tabung 7, 8, dan 9 adalah tabung untuk kontrol negatif, masing-masing tabung diisi dengan $0,9 \mathrm{~mL}$ sukrosa $0,25 \mathrm{M}$ dalam bufer fosfat $0,2 \mathrm{M} \mathrm{pH} 7$, kemudian ditambahkan $0,1 \mathrm{~mL}$ enzim GTF, lalu ditambahkan $0,025 \mathrm{~mL}$ akuades steril, dan terakhir ditambahkan bufer fosfat $0,2 \mathrm{M}$ pH 7 sampai volume total $2 \mathrm{~mL}$. Semua tabung uji diinkubasi pada suhu $37^{\circ} \mathrm{C}$ selama 2 jam, kemudian dilakukan preparasi terhadap larutan tersebut dengan penambahan $\mathrm{Pb}$-asetat $10 \%$ dan $\mathrm{Na}-$ Oksalat 5\% disertai penyaringan dengan kertas saring. Penambahan $\mathrm{Pb}$-asetat $10 \%$ dan Na-Oksalat 5\% ini dilakukan secara berulang-ulang disertai penyaringan dengan kertas saring sampai semua larutan bewarna bening bersih dan tidak terbentuk endapan putih, kemudian larutan tersebut disaring dengan membran filter nilon. Konsentrasi fruktosa diuji dengan HPLC, dengan menyuntikkan $2 \mu \mathrm{L}$ larutan uji atau larutan kontrol, kemudian dilihat waktu retensinya. Kadar fruktosa dihitung melalui pembacaan luas area fruktosa berdasarkan konsentrasi larutan standar fruktosa dengan rumus sebagai berikut: ${ }^{14}$

$$
\text { Konsentrasi (\%) }=\underline{\{(\mathrm{AC} / \mathrm{AS}) \times(\mathrm{VIS} / \mathrm{VIC}) \times \mathrm{FP}\}} \times 100 \%
$$

KS

Keterangan :

$\mathrm{AC}=$ Area Contoh

$\mathrm{AS}=$ Area Standar

VIC $=$ Volume Injek Contoh

VIS $=$ Volume Injek Standar

$\mathrm{KS}=$ Konsentrasi Standar

$\mathrm{FP}=$ Faktor Pengenceran

Satu unit aktivitas enzim GTF di definisikan sebagai $1 \mu \mathrm{mol} / \mathrm{mL}$ fruktosa dari enzim/jam. ${ }^{13}$ Data hasil penelitian ini dianalisis dengan one-way ANOVA.

\section{HASIL}

Penelitian ini menunjukkan adanya perbedaan rerata Aktivitas enzim GTF dari masing-masing perlakuan. Aktivitas GTF setelah paparan EDK 10\% adalah 7,733 , dimana aktivitas ini hanya sepertiga aktivitas GTF pada kontrol. Perbedaan rerata aktivitas enzim GTF pada masing-masing kelompok uji terdapat pada Tabel 1.
Tabel I. Hasil pengukuran aktivitas enzim glukosiltransferase (GTF) menggunakan HPLC

\begin{tabular}{llll}
\hline No. & Kelompok Uji & n & Rerata \pm SE \\
\hline 1 & Kontrol Positif & 3 & $2,293 \pm 2,293$ \\
2 & EDK 10\% & 3 & $7,733 \pm 4,127$ \\
3 & Kontrol Negatif & 3 & $25,966 \pm 6,801$ \\
\hline
\end{tabular}

Keterangan $: \mathrm{n}=$ jumlah sampel, $\mathrm{SE}=$ standard error

Aktivitas enzim GTF yang cukup rendah pada kontrol positif dan EDK 10\% menunjukkan sintesis glukan dan fruktosa bebas dari substrat sukrosa berjalan lambat. Rerata aktivitas GTF yang paling tinggi pada kontrol negatif menunjukkan bahwa tidak adanya penghambatan aktivitas enzim GTF pada penggunaan akuades steril yang menyebabkan reaksi biokimia saat sintesis glukan dan fruktosa bebas dari substrat sukrosa berjalan dengan cepat. Hasil tersebut berdasarkan pengukuran jumlah konsentrasi fruktosa bebas yang kemudian dilakukan pengukuran jumlah konsentrasinya dengan menggunakan HPLC. Penelitian ini menggunaan HPLC dengan fase diam $-\mathrm{NH}_{2}$ karena dilakukan pemisahan fruktosa yang merupakan senyawa monosakarida. Fruktosa dalam penelitian ini merupakan salah satu produk sintesis dari enzim GTF bakteri $S$. mutans. Rendahnya jumlah konsentrasi fruktosa yang terbentuk, dapat diasumsikan sebagai keberhasilan penghambatan aktivitas enzim GTF bakteri $S$. mutans.

Hasil uji one-way ANOVA pada data hasil penelitian ini menunjukkan signifikansi $0,029(p<0,05)$ yang menunjukkan adanya penurunan aktivitas enzim GTF yang bermakna antar kelompok uji, selanjutnya uji analisis post hoc LSD.

\section{PEMBAHASAN}

Rerata aktivitas enzim GTF yang paling tinggi terlihat pada kontrol negatif. Perbedaan rerata aktivitas enzim GTF pada kontrol negatif (akuades steril) dengan kontrol positif (klorheksidin glukonat), maupun EDK $10 \%$, menunjukkan terdapat hambatan aktivitas enzim GTF oleh mekanisme antibakteri pada kontrol positif dan EDK 10\%. Hal ini menunjukkan bahwa senyawa antibakteri mampu menghambat aktivitas enzim GTF bakteri $S$. mutans. ${ }^{13,15}$ Kersen merupakan tanaman yang memiliki kandungan senyawa antibakteri. Tanin, flavonoid, dan senyawa-senyawa etanolik dalam daun kersen adalah senyawa-senyawa yang diduga memiliki kemampuan sebagai antibakteri. Penelitian ini menggunakan EDK 10\% yang memiliki kemampuan menghambat kerja enzim GTF bakteri $S$. mutans. Tanin memiliki kemampuan bakteriostatik dan bakteriosid, gallotanin merupakan bagian dari senyawa tanin terhidrolisis yang merupakan komponen aktif senyawa etanolik. Gallotannin mampu menghambat 
pembentukan glukosa dari bakteri $S$. mutans dan $S$ sobrinus. ${ }^{16}$ Mekanisme antibakteri tanin antara lain menghambat enzim ektraseluler bakteri, mengambil alih substrat yang dibutuhkan pada pertumbuhan bakteri, atau bekerja langsung pada metabolisme dengan cara menghambat fosforilasi oksidasi. ${ }^{17}$

Flavonoid pada daun kersen memiliki peran yang sama halnya seperti tanin, sebagai antibakteri. Mekanisme kerja senyawa flavonoid sebagai antibakteri adalah flavonoid mampu melepaskan energi tranduksi terhadap membran sitoplasma bakteri serta menghambat motilitas bakteri. Senyawa flavonoid memiliki subdivisi flavonoid berupa flavones (apigenin) dan flavonols. Apigenin merupakan komponen paling efektif dalam menghambat enzim GTF, terutama GTFB dan GTFC, sehingga mampu mengurangi perlekatan dan pembentukan koloni $S$. mutans. ${ }^{19}$

Perbedaan yang bermakna antara kontrol positif dengan kontrol negatif serta EDK 10\% dengan kontrol negatif membuktikan bahwa terdapat pengaruh penggunaan EDK 10\% dalam penghambatan aktivitas enzim GTF melalui mekanisme antibakteri yang dimilikinya, namun diperlukan pembanding untuk mengetahui konsentrasi EDK yang paling efektif dalam menghambat aktivitas enzim GTF. Penggunaan kontrol positif dan kontrol negatif pada penelitian ini menjadi indikator efektivitas dari EDK 10\%. Penelitian ini dilakukan dengan menggunakan klorheksidin glukonat $0,12 \%$ sebagai kontrol positif. Penggunaan klorheksidin glukonat $0,12 \%$ sebagai kontrol positif karena klorheksidin glukonat merupakan standar baku obat kumur. ${ }^{20}$ Penggunaan klorheksidin glukonat ini sesuai dengan penelitian terdahulu, ${ }^{21}$ untuk mengetahui kemampuan penghambatan klorheksidin glukonat terhadap aktivitas enzim GTF. Hasil dari penelitian ini menunjukkan bahwa tidak terdapat perbedaan yang bermakna antara kontrol positif dengan EDK 10\%. Ekstrak daun kersen konsentrasi 10\% memiliki kemampuan yang hampir sama dengan kemampuan klorheksidin glukonat $0,12 \%$ sebagai antibakteri dalam menghambat aktivitas enzim GTF bakteri $S$. mutans, meskipun hasil ini masih diperlukan penelitian lebih lanjut. Perbedaan rerata aktivitas enzim GTF dalam penelitian ini mengindikasikan adanya perbedaan kemampuan penghambatan enzim GTF dari masingmasing kelompok uji. Penghambatan aktivitas enzim GTF bakteri $S$. mutans berperan penting dalam upaya pencegahan karies gigi. Rendahnya rerata aktivitas enzim GTF dari bakteri S. mutans dapat memperkecil kemungkinan terjadinya karies gigi karena aktivitas enzim GTF dalam rongga mulut telah dikendalikan. ${ }^{15}$

\section{SIMPULAN}

Ekstrak daun kersen konsentrasi 10\% dapat menghambat aktivitas enzim GTF $S$. mutans.

\section{DAFTAR PUSTAKA}

1. Higham S. Caries process and prevention strategies: the agent. [Internet]. [cited 2010 May 4]. Available from: http://www.dentalcare.com/en-US/dentaleducation.

2. Nugraha AW. S mutans: si plak dimana-dimana. Yogyakarta: Fakultas Farmasi USD; 2008. Indonesian

3. Depkes RI. Riset Kesehatan Dasar (RISKESDAS) 2007. Jakarta; 2008 Indonesian.

4. Samaranayake LP, Jones BM, Scully C. Essential microbiology for dentistry, Edinburgh: Churchill Livingstone; 2002.

5. Lavelle CLB. Aplied oral physiology, 2nd ed. London: Wright; 2002.

6. Roeslan BO. Karakteristik $S$. mutans penyebab karies gigi. Majalah Ilmiah FKG Usakti. 1995;10:112-25. Indonesian.

7. Lehner T, Ma JK, Kelly CG. A mechanism of passive immunization with monoclonal antibodies to a 185,000 M(r) streptococcal antigen. Adv Exp Med Biol. 1992;327:151-63.

8. Singh J, Kumar A, Budhiraja S, Hooda A. Ethnomedicine: use in dental caries. Braz J Oral Sci. 2007;6:1308-12.

9. Wiryowidagdo S. Perkembangan dan masa depan mikrobiologi. Dalam: Kursus singkat Pengontrolan Kualitas Bahan Pangan secara Mikrobiologi. Ujung Pandang : Fakultas MIPA Universitas Hasanuddin. 1996. Indonesian.

10. Warung Riset Teknologi (WARINTEK). Muntingia calabura L. Jakarta : Kementerian Negara Riset dan Teknologi. 2006 [Internet]. [cited 2012 Oct 24]. Available from: http://www.warintek.ristek.go.id/ pangan_kesehatan/tanaman_obat/depkes/3-077. pdf. Indonesian.

11. Hidayaningtias P. Perbandingan efek antibakteri air seduhan daun sirih (Piper betle L.) terhadap Streptococcus mutans pada waktu kontak dan konsenterasi yang berbeda [dissertation]. Semarang: Universitas Diponegoro; 2008. Indonesian.

12. Zakaria ZA, Fatimah CA, Mat Jais AM, Zaiton H, Henie EFP, Sulaiman MR, et al. The in vivo antibacterial activity of Muntingia calabura extract. Int J Pharmacol. 2006;2:439-42.

13. Park YK, Koo MH, Abreu JAS, Ikegaki M, Cury JA, Rosalen PL. Antimicrobial activity of propolis on oral microorganisms. Curr Microbiol. 1998; 36:24-8.

14. Putriyanti D. Identifikasi fruktosa pada beberapa jenis tape serta pengamatan perubahan mikrobiologis dan biokimiawi tape singkong selama fermentasi [undergraduate thesis]. Bogor: Fakultas Teknologi Pertanian IPB; 1990. Indonesian.

15. Ikeno K, Ikeno T, Miyazawa C. Effect of propolis on dental caries in rats. Caries Res. 1991;25:34751 . 
16. Wu Yuan CD, Chen CY, dan Wu RT. Gallotannis inhibit growth, water-insoluble glucan synthesis, and aggregation of mutans Streptococci. J Dent Res. 1998; 67:51-5.

17. Scalbert A. Antimicrobial properties of tannins phytochemistry. INRA. 1991;30:3875-83.

18. Mirzoeva OK, Grishanin RN, Calder PC. Antimicrobial action of propolis and some of its components: the effects on growth, membrane potential, and motility of bacteria. Microbiol Res. 1997;152:239-46.
19. Koo H, Rosalen PL, Cury JA, Park YK, Bowen WH. Effects of coumpounds found in propolis on Streptococcus mutans growth and on glucosyltransferase activity. Antimicrob. Agents Chemother. 2002;46:1302-9.

20. Srinivasan M, Eapen BR, Bhas G, Kumar C. Efficacy of chlorhexidine mouthwash as an oral antiseptic in vivo study on 20 patients. Middle East J Fam Med. 2005;3:11-3.

21. Scheie A, Kjeilen J. Effects of chlorhexidine, $\mathrm{NaF}$ and $\mathrm{SnF} 2$ on glucan formation by salivary and culture supernatant GTF absorbed to hydroxyapatite. Scand J Dent Res. 1987;95:532-5. 